\title{
Analiza uwarunkowań zapewnienia prawidłowej trajektorii w zrobotyzowanych aplikacjach spawania łukowego MIG/MAG
}

\author{
Analysis of proper trajectory assurance \\ in robotized applications \\ of MIG/MAG Welding
}

\section{Streszczenie}

Robotyzacja spawania, w przeciwieństwie do mechanizacji i prostej automatyzacji, pozwala na niemal dowolne kształtowanie trajektorii, po jakiej poruszać się będzie narzędzie, np. spawalniczy uchwyt elektrodowy, nawet w połączeniu z równoczesnymi ruchami odpowiednio zsynchronizowanego pozycjonera czy toru, poruszającego robot. Przyczyną błędów i niezgodności spawalniczych mogą być problemy z prawidłowym odtwarzaniem zadanej trajektorii przez nieprawidłowo zaprogramowany bądź wyeksploatowany robot. W artykule przedstawiono ogólne zagadnienia sterowania oraz autorską metodykę określania błędów pozycjonowania robota spawalniczego wraz z analizą przyczyn i konsekwencji nieprawidłowej pracy napędów.

Słowa kluczowe: robot spawalniczy; trajektoria; zużycie; spawanie łukowe

\begin{abstract}
The welding process with the use of industrial robot, comparing to mechanized processes, allows for almost arbitrary trajectory forming of the movement of a tool being used, such as e.g. welding electrode holder. This can be combined with the simultaneous movements of synchronized positioner or on the robot moving rail. Possible welding imperfections that might occur can result either of the improper following up the programmed trajectory or robot inaccuracy. Some general issues of a robot control as well as author's methodology of the identification of robot positioning errors are described in this paper. An analysis and results of improper action of power transmissions used is also presented.
\end{abstract}

Keywords: welding robot; trajectory; wear; arc welding

\section{Wprowadzenie}

Robot spawalniczy pozwala na powtarzalne wykonywanie w ramach pojedynczego cyklu roboczego wielu spoin o różnym kształcie i położeniu w przestrzeni, także w połączeniu z równoczesnymi ruchami odpowiednio zsynchronizowanego pozycjonera czy toru jezdnego. Niestety, nawet jeśli spawane elementy i oprzyrządowanie przygotowane będą z najwyższą starannością $[3,4]$, a także zachowane zostaną wysokie standardy wyznaczania i utrzymania punktu roboczego TCP [2], nieprawidłowo zaprogramowany bądź nadmiernie wyeksploatowany ro- bot może spowodować błędy pozycjonowania i w konsekwencji niezgodności spawalnicze.

Nieprawidłowości związane z programowaniem to przede wszystkim niestosowanie prawidłowych definicji w odniesieniu do ruchu roboczego spawania. Nadmierne wyeksploatowanie jest objawem zużycia maszyny, rozumianego jako utrata (obniżenie) pierwotnych właściwości i parametrów. Zużycie może być naturalne, zmęczeniowe, a także ekonomiczne (zwane „moralnym"), np. ze względu na postęp techniczny. Obydwa zagadnienia omówione zostaną szerzej w dalszej części artykułu.

dr inż. Paweł Cegielski - Politechnika Warszawska.

Autor korespondencyjny/Corresponding author: pcegiels@wip.pw.edu.pl 


\section{Elementy sterowania robotów}

Sterowanie (regulacja) to działanie na określony układ (obiekt sterowany), za pomocą sygnałów wejściowych, mające na celu zapewnienie jego zachowania się w żądany sposób - tak, aby sygnały wyjściowe osiągnęły założoną wartość. Niepożądane i nieplanowane sygnały wejściowe to zakłócenia.

Sterowanie może być ręczne, tzn. takie, w którym człowiek odgrywa rolę przynajmniej jednego członu układu sterowania, lub automatyczne, wykorzystujące specjalnie w tym celu skonstruowany układ - regulator. Sterowanie automatyczne może dotyczyć zarówno najprostszych systemów o ograniczonych możliwościach kształtowania toru ruchu, realizujących proste cykle robocze, jak i robotów przemysłowych.

W sensie ogólnym, automat jest urządzeniem zawierającym odizolowane od środowiska przetworniki informacji oraz sztuczne receptory (czujniki) i efektory (elementy wykonawcze). Działanie receptorów, jako efekt wpływu otoczenia, wywołuje z kolei działanie efektorów, a odbywa się to bez udziału człowieka (rys. 1). Strefy: obsługowa i pomiarowa wyznaczają tzw. otoczenie techniczne automatu (robota), natomiast środowisko, w którym pracuje, to zbiór mechanizmów i urządzeń niewchodzących w jego skład. Pozostają one w interakcji, przy czym bezpośrednie oddziaływanie pomiędzy automatem i środowiskiem jest efektem niedoskonałości izolatorów i ma charakter przeważnie niekorzystny, zakłócając jego pracę. [10].

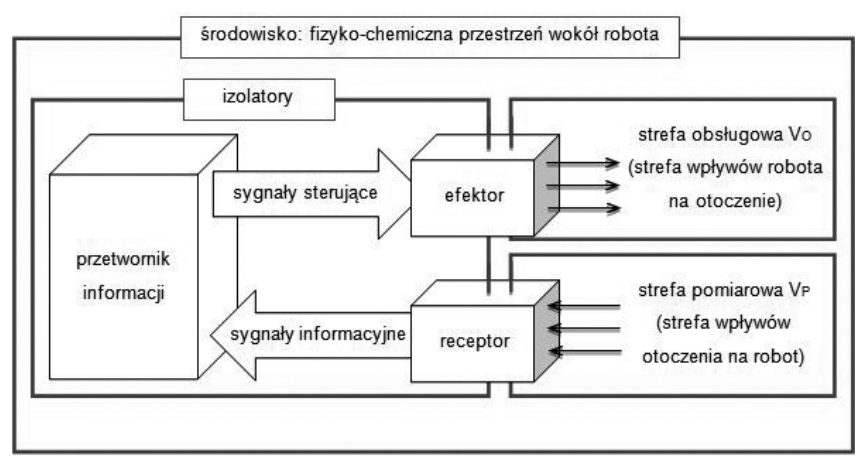

Rys. 1. Struktura systemu współdziałania automatu z otoczeniem [10] Fig. 1. The structure of cooperation between an automat and its neighbourhood [10]

Sterowanie, zarówno ręczne, jak i automatyczne, może odbywać się w układzie zamkniętym oraz otwartym. Podczas sterowania w układzie zamkniętym, operator (człowiek) lub automatyczny regulator (układ sterujący) otrzymują, w odpowiedniej formie (napięcie, wskazania miernika itp.), bieżące informacje o stanie wielkości wyjściowych sterowanego obiektu. Następnie, informacje te są wykorzystywane do korygowania nastaw wielkości wejściowej przez sprzężenie zwrotne - sterowanie z ujemną pętlą sprzężenia zwrotnego. Stabilizuje to przebieg sterowanego procesu i pozwala na wyeliminowanie wpływu wielkości zakłócających. Sterowanie automatyczne z pętlą sprzężenia zwrotnego (jedną lub wieloma pętlami) określane jest mianem układu automatycznej regulacji i jest właściwe $m$.in. dla napędów robotów przemysłowych. Schemat blokowy takiego układu przedstawiono na rysunku 2, gdzie: $A$ - węzeł sumacyjny, gdzie wartość mierzona $y$ jest porównywana z wartością zadaną $x$ regulowanej wielkości tak, aby wartość mierzona $y$ równała się wartości zadanej $x$. $B$ - węzeł zaczepowy (pomiarowy).

Sterowanie jednostkami napędowymi, np. robotów, z punktu widzenia sposobu zadawania pozycji często

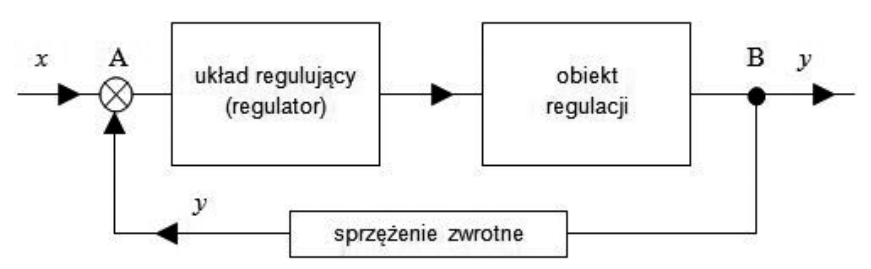

Rys. 2. Schemat układu automatycznej regulacji

Fig. 2. The scheme of an automatic control system

potocznie rozróżniane jest jako ciągłe lub dyskretne. W pierwszym przypadku wykorzystującym sterowanie ze sprzężeniem zwrotnym (serwomechanizmy), możliwe jest programowe zadawanie dowolnej prędkości, a przede wszystkim pozycji, do jakiej się przemieści napędzany mechanizm. Sterowanie dyskretne, zwane także podziałowym, polega na zajmowaniu przez mechanizm tylko określonych pozycji i może wynikać:

- z cech konstrukcyjnych zastosowanego napędu (np. dwustanowego pneumatycznego);

- specjalnej konstrukcji mechanizmu (z podziałowym, mechanicznym blokowaniem w określonych położeniach);

- z programu sterującego (podział uzyskany na drodze programowej).

W odniesieniu do szerokiej grupy robotów przemysłowych przyjęto wyróżniać, ze względu na możliwość zajęcia przez poszczególne zespoły ruchu określonej liczby zadanych położeń, sterowanie:

- wielopunktowe MP (ang. Multi Point), o większej niż dwa liczbie zadawanych pozycji przypadających na zespół ruchu, z torem opisanym w postaci kolejno po sobie następujących punktów podporowych (rys. 3a);

- ciągłe CP (ang. Continuos Path), z zadawaniem trajektorii w postaci ciągłej ścieżki; umożliwia powtarzalne odtwarzanie trajektorii bez wykorzystania pośrednich punktów podporowych (rys. 3b);

- wielopunktowe MP z interpolatorami: liniowym, kołowym czy spline (rys. 3c).

a)
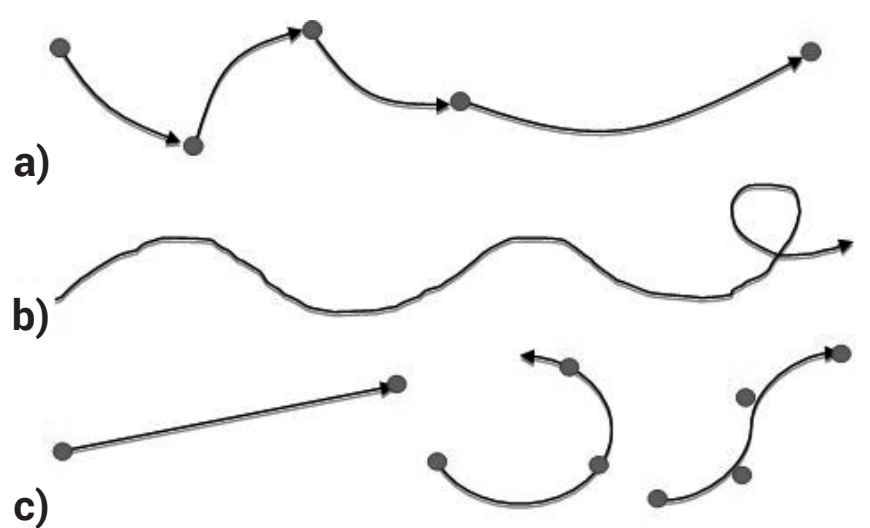

Rys. 3. Istota tworzenia trajektorii ruchu robota przemysłowego: a) MP, b) CP, c) MP z interpolatorami

Fig. 3. The idea of the industrial robot movement trajectory creation: a) MP, b) CP, c) MP with interpolators

Sterowanie wielopunktowe MP odbywa się po torze wyznaczonym przez punkt: początkowy, pośrednie i końcowy, bez określania kształtu toru ruchu. Dzięki jednoczesnemu przemieszczaniu kilku zespołów ruchu, z pośredniczącymi w przejściu punktami podporowymi (pośrednimi), możliwe jest dowolne kształtowanie toru ruchu. Przy sterowaniu ciągłym CP kontrolowane jest zarówno odchylenie od zadanego toru, jak i prędkość ruchu. Obecnie, w odniesieniu do szerokiej grupy uniwersalnych robotów przemysłowych, sterowanie przyjmuje najczęściej postać wielopunktową MP, 
uzupełnioną o interpolatory (np. liniowy czy kołowy). Dzięki temu, możliwe staje się przemieszczenie po precyzyjnie określonej linii ciągłej, np. prostej, między parami kolejnych punktów podporowych toru.

Układy napędowe przy sterowaniu zespołami ruchu pozycjonowanymi w całym zakresie przemieszczeń (MP, CP) muszą zapewnić możliwość osiągania stabilnych położeń w dowolnych punktach. W tym celu stosowane są serwonapędy, zawierające przetworniki położenia wytwarzające sygnały sprzężenia zwrotnego, informujące o rzeczywistym położeniu napędzanej osi. Ze względu na charakter zmian wartości zadanej wyróżnia się dwa typy regulacji położenia [9]:

- Przestawianie - typowe dla sterowania wielopunktowego MP. Charakteryzuje się wymuszaniem następnej wartości zadanej dopiero po uzyskaniu, z określoną dokładnością, poprzedniej wartości zadanej (rys. 4), gdzie: $x(t)$ - zmiany położenia, $t_{r 1}, t_{r 2}$ - czasy regulacji, $\varepsilon_{\mathrm{s}}$ - odchyłka statyczna.

- Nadążanie - charakterystyczne dla sterowania ciągłego CP (w tym sterowania wielopunktowego z interpolatorami). W odróżnieniu od przestawiania nadążanie cechuje się ciągłymi zmianami wartości zadanej, ma więc charakter dynamiczny.

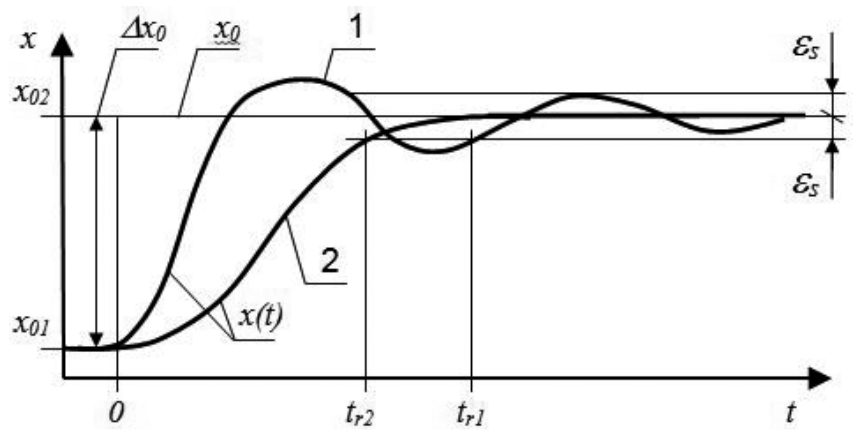

Rys. 4. Regulacja położenia - przestawianie [9]

Fig. 4. The location regulation - transposition [9]

\section{Elementy programowania ruchu roboczego podczas spawania}

Programowanie zautomatyzowanych maszyn manipulacyjnych, w tym robotów przemysłowych, polega na wprowadzeniu do pamięci jej układu sterowania, dla każdego kolejnego kroku, algorytmu jej pracy w postaci [9]:

- instrukcji, określającej rodzaj działania podstawowego, jakim jest przemieszczenie i pomocniczego, określającego współpracę ze środowiskiem roboczym;

- argumentów instrukcji, określających zakres i parametry określonych instrukcją działań.

Do najważniejszych powinności układu sterowania robota przemysłowego zaliczyć należy sterowanie zespołami ruchu, pozycjonowanymi w całym zakresie przemieszczeń. Zagadnienie to obejmuje m.in. ustalenie kierunków, prędkości i ewentualnych przyspieszeń ruchu poszczególnych członów (sterowanych osi układu nośnego), a także koordynację między ruchami wykonywanymi jednocześnie, w dwóch lub w $n>2$ osiach [5].

Roboty przemysłowe, posiadające wieloosiowe zespoły ruchu o szerokim zakresie przemieszczeń, umożliwiają szybkie przystosowanie do wykonywania różnych operacji, w tym odtwarzanie złożonych trajektorii ruchu. Ich układy sterowania pozwalają na łatwe zaprogramowanie, np. metodami uczenia, oraz osiąganie stabilnych położeń w dowolnych punktach przestrzeni roboczej.
Jak już wspomniano, jedną z przyczyn błędów pozycjonowania i w konsekwencji niezgodności spawalniczych mogą być problemy z prawidłowym odtwarzaniem zadanej trajektorii wskutek nieprawidłowo zaprogramowanego ruchu roboczego. Podstawowy sposób programowania ruchu w szerokiej grupie robotów przemysłowych, w tym spawalniczych, odpowiada sterowaniu wielopunktowemu MP. W jego trakcie możliwe jest jednoczesne przemieszczanie kilku zespołów napędowych (osi), pozwalające na swobodne kształtowanie toru, po jakim porusza się organ roboczy. Niestety, równoczesny ruch wszystkich osi koniecznych dla danego przemieszczenia pociąga za sobą nieznaną trajektorię (dla robotów z osiami obrotowymi zwykle w kształcie łuku) i prędkość, zwykle wyższą od zadanej z uwagi na konieczność pokonania większej drogi (rys. 5 - linia oznaczona QLIN). Jest to zatem rozwiązanie podstawowe, które praktycznie nie powinno być stosowane w odniesieniu do bezpośredniego programowania ruchów roboczych, np. trajektorii spoin.

Skutecznym rozwiązaniem zagadnienia kontroli programowanej trajektorii, a zarazem kompromisem pomiędzy sterowaniem MP a ciągłym CP, jest sterowanie wielopunktowe MP uzupełnione o interpolatory: liniowy, kołowy, a nawet typu spline (rys. 3c i 5). Możliwa staje się synchronizacja ruchów poszczególnych osi składowych w celu realizacji przemieszczenia po określonej linii ciągłej - na ogół prostej lub kołowej, między parami kolejnych punktów toru. Jest to tzw. sterowanie "niby-ciągłe”, z ciągłą kontrolą toru ruchu i prędkości pomiędzy punktami podporowymi, obecnie dominujące w szerokiej grupie robotów uniwersalnych, także spawalniczych. Dla przypadku pokazanego na rysunku 5 ruch z zadaną interpolacją liniową (LIN), zaprogramowany pomiędzy kolejnymi punktami A i B, spowoduje przejście liniowe tylko tej części narzędzia, która została prawidłowo zadeklarowana jako punkt roboczy (TCP), nawet jeśli orientacje (pochylenie) narzędzia były różne w punktach początkowym i końcowym.

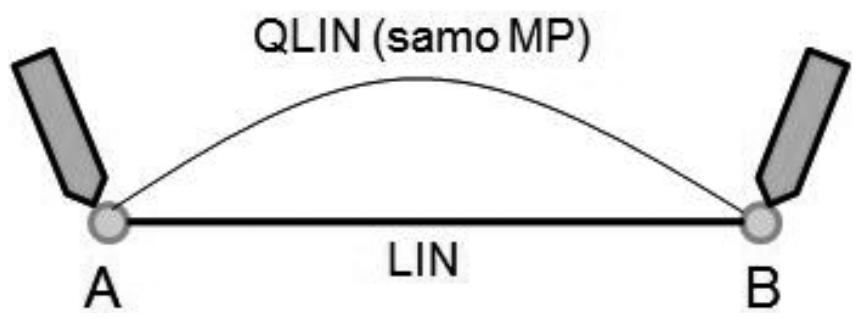

Rys. 5. Istota ruchów interpolowanych liniowo (LIN) Fig. 5. The idea of linear interpolation movements (LIN)

Błędem programisty, skutkującym nieprawidłowym odtwarzaniem trajektorii, jest programowanie ruchów roboczych, np. spawania, bez udziału interpolatorów. Przyczyną takiego stanu, oprócz nieuwagi czy niewiedzy, mogą być pozorne korzyści wynikające ze stosowania ruchów bez interpolacji. Najważniejszą, jest wykonalność ruchu nieinterpolowanego, rozumiana jako zdolność do znalezienia ścieżki pomiędzy dwoma następującymi po sobie, wskazanymi w trakcie programowania punktami toru ruchu. Przeciwnie, ruchy interpolowane nie zawsze mogą być wykonane we wskazanym zakresie przemieszczenia, głównie za sprawą osiągania przez niektóre osie położeń krytycznych (poza granicą ruchu). Niestety, brak interpolacji podczas programowania robotów z osiami obrotowymi (a więc większości spawalniczych o strukturze antropomorficznej) zawsze skutkuje odchyleniem od linii prostej pomiędzy zadanymi punktami toru (rys. 5). 
Stopień i kierunek odchylenia zależą m.in. od zakresu ruchu (odległości między zaprogramowaną parą punktów) i ich położeniem względem podstawy robota, i są niezmienne przy kolejnych powtórzeniach tej samej trajektorii. Niekiedy można odnieść wrażenie liniowości ruchu nieinterpolowanego, nawet jednak 0,5 mm odchylenia przy wykonywaniu spoiny pachwinowej może skutkować niezgodnościami kształtu, a nawet przyklejeniami w środkowej części złącza [3].

Poniżej przytoczono wyniki prostego eksperymentu wykonanego przy użyciu robota IRp-6, polegającego na zaprogramowaniu różnych wariantów ruchu pomiędzy dwoma punktami wzdłuż prostoliniowej listwy testowej, ustawionej prostopadle do osi X układu bazowego robota (rys. 6).
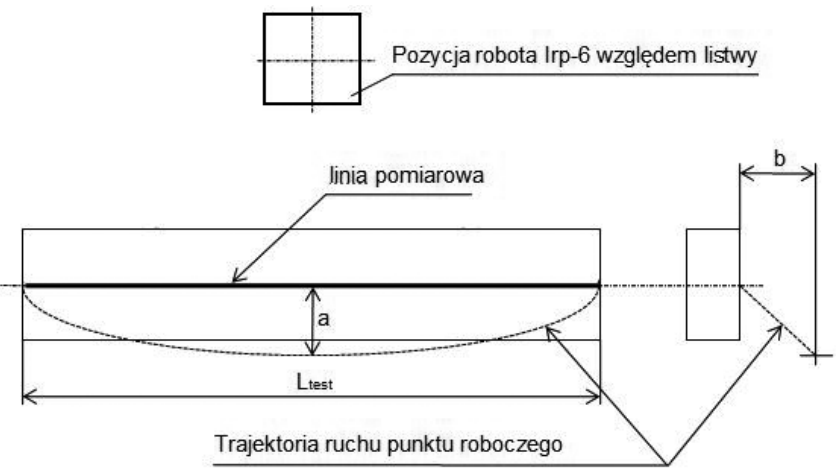

Rys. 6. Schemat procedury testowej: $a, b-$ mierzone odchylenia trajektorii ruchu, $\mathrm{L}_{\text {test }}$ - długość odcinka testowego $(5$ i $200 \mathrm{~mm}$ ) Fig. 6 . The scheme of testing procedure: $a, b-$ measured deviations of movement trajectory, $L_{\text {test }}-$ test length ( 5 and $200 \mathrm{~mm}$ )

Orientacja narzędzia ustalona była jako stała - pionowa (wariant I) oraz zmienna w jednej płaszczyźnie (odchylenie od pionu w punkcie początkowym i końcowym +/- 300, wariant II). Podczas każdego przejścia zatrzymywano ruch w połowie odcinka testowego i dokonywano pomiaru maksymalnych odchyleń końcówki roboczej narzędzia od zaprogramowanego toru zgodnie z rysunkiem 6. Prędkość ruchu testowego - $25 \mathrm{~mm} / \mathrm{sek}$. Ruch programowano jako liniowy (z interpolatorem) - LIN, jak i bez interpolacji - QLIN. W celach porównawczych, definicje punktu roboczego narzędzia (TCP) zaprogramowano w dwóch wariantach: dowolnie (narzędzie nr 1) i zgodnie z rzeczywistymi parametrami narzędzia (nr 2). Wyniki zebrano w tablicach I i II.
Stwierdzono, że pełną kontrolę trajektorii i prędkości dla ruchu prostoliniowego można osiągnąć jedynie w wyniku precyzyjnego ustalenia punktu roboczego narzędzia (TCP) i zastosowania interpolatora liniowego. Nie jest przy tym już tak ważne, czy ruch odbywał się będzie ze stałą orientacją, czy też orientacja będzie się zmieniała. Biorąc pod uwagę fakt, że testy prowadzone były z prędkością znacznie przewyższającą typowe prędkości spawania łukowego, zagadnienie prędkości zmiany orientacji i wynikających stąd negatywnych konsekwencji będzie, podczas znacznie wolniej prowadzonego spawania, pomijalne. Powyższe wnioski można uznać za słuszne także w odniesieniu do współcześnie produkowanych robotów spawalniczych. Potwierdzono to podczas prób programowania takich jednostek jak Kawasaki FA06E, RS 20 N czy Fanuc Arc Mate 0iB.

Programowanie ruchu bez interpolacji, często jako domyślne, dostępne jest w większości robotów uniwersalnych i spawalniczych, np. pod postacią komendy QLIN (w robotach serii IRp-6, ZAP-Robotyka) czy JOINT (dla robotów Kawasaki i szeregu innych). Poniżej, przedstawiono fragment kodu zawierającego pełne składnie komend ruchu bez interpolacji (QLIN) i z interpolacją liniową (LIN) robota IRp-6. Obydwa zapisy zawierające takie same, dokładne informacje o parametrach i współrzędnych ruchu, mogą błędnie sugerować jednakowy charakter ruchu:

0: 30 POZ QLIN V = 50\% ZGRUBN BZWG

$X=714.95 \mathrm{MM}, Y=0 \mathrm{MM}, Z=255.11 \mathrm{MM}$

$\mathrm{N}=102.96 \mathrm{DEG}, \mathrm{P}=-176.91 \mathrm{DEG}$

0: 40 POZ LIN V = 50\% ZGRUBN BZWG

$X=669.67 \mathrm{MM}, Y=-576.8 \mathrm{MM}, Z=55.9 \mathrm{MM}$

$N=119.84 D E G, P=170.68 D E G$

W przypadku robotów przemysłowych Kawasaki dostępny jest bardzo wygodny, blokowy język programowania, pozwalający na szybką obsługę prostych zadań, także spawalniczych (jego uzupełnieniem jest zaawansowany język tekstowy AS). Programowanie w tym trybie polega na bezpośrednim wskazywaniu, a następnie zapisywaniu w programie, punktów w przestrzeni. Kolejno ponumerowane wiersze - bloki (rys. 7) zawierają, oprócz deklaracji rodzaju i interpolacji ruchu (kolumna INTERP), uproszczone dane pomocnicze odniesione do zapisów konfiguracyjnych systemu, w tym prędkość ruchu (SPD), jego dokładności (ACC), opóźnienie (TMR), odwołanie do definicji TCP narzędzia (TOOL) oraz działania na jednobitowych wejściach i wyjściach komunikacyjnych (OUTPUT,

Tablica I. Wyniki badań dla odcinka testowego $5 \mathrm{~mm}$

Table I. Test results for test length of $5 \mathrm{~mm}$

\begin{tabular}{|c|c|c|c|c|c|c|}
\hline \multicolumn{4}{|c|}{ Dane wejściowe } & \multicolumn{3}{|c|}{ Wynik } \\
\hline $\begin{array}{c}\mathrm{L}_{\text {test }} \\
{[\mathrm{mm}]}\end{array}$ & Definicja narzędzia & $\begin{array}{c}\text { Sposób } \\
\text { pozycjonowania robota }\end{array}$ & $\begin{array}{c}\text { Rodzaj } \\
\text { ruchu }\end{array}$ & $\begin{array}{c}\text { Charakter } \\
\text { zmiany orientacji }\end{array}$ & $\mathrm{a}[\mathrm{mm}]$ & b [mm] \\
\hline \multirow{8}{*}{5} & \multirow{4}{*}{$\begin{array}{c}\mathrm{Nr} \mathrm{1:} \\
\mathrm{N}=135^{\circ}, \mathrm{P}=0^{\circ} \\
\mathrm{x}=88 \mathrm{~mm}, \mathrm{y}=0 \mathrm{~mm} \\
\mathrm{z}=246 \mathrm{~mm}\end{array}$} & \multirow{2}{*}{ LIN } & I & - & 0 & 0 \\
\hline & & & II & nieproporcjonalny & 6,0 & 1,5 \\
\hline & & \multirow{2}{*}{ QLIN } & I & - & 0 & 0 \\
\hline & & & II & proporcjonalny & 0 & $-0,5$ \\
\hline & \multirow{4}{*}{$\begin{array}{c}\mathrm{Nr} 2: \\
\mathrm{N}=70^{\circ}, \mathrm{P}=180^{\circ} \\
\mathrm{x}=0 \mathrm{~mm}, \mathrm{y}=0 \mathrm{~mm} \\
\mathrm{z}=336 \mathrm{~mm}\end{array}$} & \multirow{2}{*}{ LIN } & I & - & 0 & 0 \\
\hline & & & II & proporcjonalny & 0 & 0 \\
\hline & & \multirow{2}{*}{ QLIN } & I & - & 0 & 0 \\
\hline & & & II & proporcjonalny & 0 & $-0,5$ \\
\hline
\end{tabular}


Tablica II. Wyniki badań dla odcinka testowego $200 \mathrm{~mm}$

Table II. Test results for test length of $200 \mathrm{~mm}$

\begin{tabular}{|c|c|c|c|c|c|c|}
\hline \multicolumn{4}{|c|}{ Dane wejściowe } & \multicolumn{3}{|c|}{ Wynik } \\
\hline $\begin{array}{l}L_{\text {test }} \\
{[\mathrm{mm}]}\end{array}$ & Definicja narzędzia & $\begin{array}{c}\text { Sposób } \\
\text { pozycjonowania robota }\end{array}$ & $\begin{array}{l}\text { Rodzaj } \\
\text { ruchu }\end{array}$ & $\begin{array}{c}\text { Charakter } \\
\text { zmiany orientacji }\end{array}$ & $\mathrm{a}[\mathrm{mm}]$ & b [mm] \\
\hline \multirow{8}{*}{200} & \multirow{4}{*}{$\begin{array}{c}\mathrm{Nr} \mathrm{1:} \\
\mathrm{N}=135^{\circ}, \mathrm{P}=0^{\circ} \\
\mathrm{x}=88 \mathrm{~mm}, \mathrm{y}=0 \mathrm{~mm} \\
\mathrm{z}=246 \mathrm{~mm}\end{array}$} & \multirow{2}{*}{ LIN } & I & - & 1,5 & 0 \\
\hline & & & II & proporcjonalny & 10,0 & 2,0 \\
\hline & & \multirow{2}{*}{ QLIN } & I & - & 6,0 & $-0,5$ \\
\hline & & & II & proporcjonalny & 5,0 & 0 \\
\hline & \multirow{4}{*}{$\begin{array}{c}\mathrm{Nr} 2: \\
\mathrm{N}=70^{\circ}, \mathrm{P}=180^{\circ} \\
\mathrm{x}=0 \mathrm{~mm}, \mathrm{y}=0 \mathrm{~mm} \\
\mathrm{z}=336 \mathrm{~mm}\end{array}$} & \multirow{2}{*}{ LIN } & 1 & - & 0 & 0 \\
\hline & & & II & proporcjonalny & 0 & 0 \\
\hline & & \multirow{2}{*}{ QLIN } & 1 & - & 7,0 & 0 \\
\hline & & & II & proporcjonalny & 6,0 & $-0,5$ \\
\hline
\end{tabular}

INPUT). W jednostkach uniwersalnych, takich jak testowany Kawasaki RS $20 \mathrm{~N}$, ruch nieinterpolowany wywołany komendą JOINT (rys. 7) funkcjonuje jako ustawienie domyślne, a każdy zrealizowany ruch odznaczał się deformacją trajektorii narzędzia względem linii prostej.

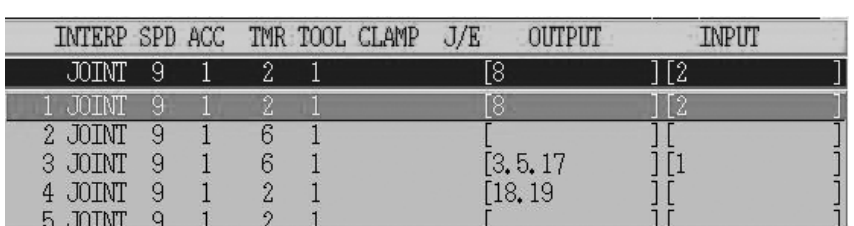

Rys. 7. Fragment programu użytkowego robota uniwersalnego (Kawasaki RS $20 \mathrm{~N}$ )

Fig. 7. The fragment of an operation programme of the universal robot (Kawasaki RS $20 \mathrm{~N}$ )

W wersjach specjalizowanych, $\mathrm{np}$. spawalniczych (testowano m.in. robot Kawasaki FA06E), zadbano o pełne „bezpieczeństwo" aplikacji technologicznych. Jak widać na rysunku 8, okno programu zyskało nowe kolumny (zbiory instrukcji), w tym:

a) Nagłówek „INS", gdzie można wybrać:

- AC - ang. Air Cut - punkt, który nie jest punktem spawania i odnosi się do ruchu ustawczego (możliwe użycie interpolatora liniowego LINEAR lub ruchu nieinterpolowanego JOINT);

- WS - ang. Weld Start - punkt początkowy, od którego zaczyna się proces spawania (możliwe użycie interpolatora liniowego LINEAR lub ruchu nieinterpolowanego JOINT);

- WC - ang. Weld Continue - punkt pośredni w trajektorii spawania (wymusza ruch interpolowany LINEAR lub CIR1 i CIR2), przy czym wymagany jest numer zbioru parametrów spawania (nagłówek "No");

- WE - ang. Weld End - punkt, w którym wygaszany jest łuk (wymusza ruch interpolowany LINEAR lub CIR2), wymagany jest numer zbioru parametrów spawania (nagłówek „No");

- S - ang. Arc Spot - punkt, w którym może być realizowana operacja zgrzewania lub spawania punktowego (możliwe użycie interpolatora liniowego LINEAR lub ruchu nieinterpolowanego JOINT).

b) Nagłówek "No" wywołujący zbiór parametrów spawania (parametry te określane są w osobnym trybie w postaci formularzy WELD CONDITION, rys. 9).

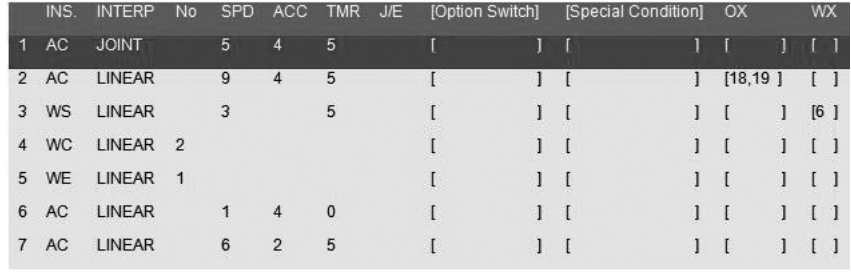

Rys. 8. Fragment programu użytkowego robota specjalizowanego - spawalniczego (Kawasaki FA06E)

Fig. 8. The fragment of operation programme of the special - welding robot (Kawasaki FA $06 \mathrm{E}$ )

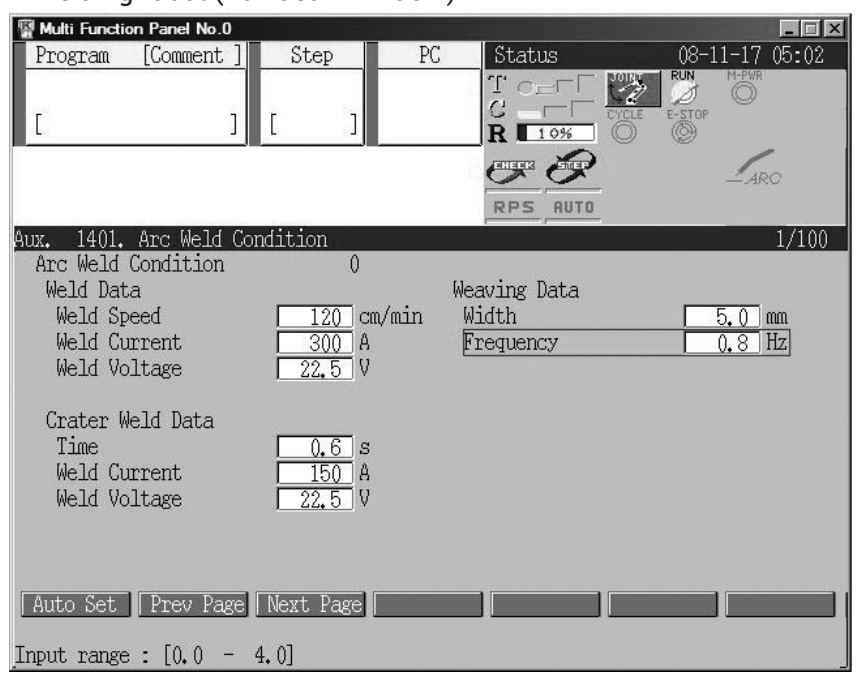

Rys. 9. Okno formularza parametrów spawania Arc Weld Condition (Kawasaki)

Fig. 9. The window of the welding parameters form Arc Welding Condition (Kawasaki)

\section{Eksploatacja robotów}

Kolejnym czynnikiem zwiększającym ryzyko błędów pozycjonowania może być nieprawidłowo użytkowany bądź nadmiernie wyeksploatowany (zużyty) robot. Eksploatacja maszyny, w tym robota, to zespół czynności obejmujący m.in.:

- użytkowanie, tj. praca sprawnej maszyny oraz bieżąca kontrola jej stanu technicznego,

- obsługiwanie, w tym przywracanie jej pierwotnego stanu technicznego (obsługa i naprawa). 
Zużycie to utrata (obniżenie) pierwotnych właściwości i parametrów, które może być naturalne, zmęczeniowe, ekonomiczne (zwane „moralnym”, np. ze względu na postęp techniczny, nawet pomimo dobrej kondycji ogólnej). W trakcie użytkowania maszyna może ulegać szeregu usterkom, zakłócającym prawidłowe funkcjonowanie, ale niepowodującym całkowitego unieruchomienia. Zignorowane usterki oraz nadmierne zużycie będą prowadzić do awarii. Jest to stan niesprawności obiektu uniemożliwiający jego funkcjonowanie, nagły, powodujący jego niewłaściwe działanie lub całkowite unieruchomienie. Stwierdzenie awarii na ogół nie wymaga użycia aparatury kontrolnej (w przeciwieństwie do usterek), a skala i moment wystąpienia często nie są możliwe do przewidzenia.

Roboty przemysłowe przygotowane są wprawdzie do nieprzerwanej pracy, jednak wysokie obciążenia i trudne warunki środowiskowe mogą być źródłem przyspieszonego zużycia. Napędom robotów przemysłowych stawiane są przy tym bardzo wysokie wymagania, w tym:

- wiele stopni swobody - wiele napędów do równoczesnego sterowania, mających wpływ na ostateczne odtwarzanie ścieżki narzędzia roboczego;

- praca ze znacznymi obciążeniami, przede wszystkim pochodzącymi od masy własnej ramienia (przykładowo manipulator robota spawalniczego o nośności 6 kg waży nie mniej niż 120-150 kg!);

- duża dynamika obciążeń, przeważnie inercyjnych (masowych);

- długotrwała praca w stanie bezruchu elementu roboczego (pracujący automatycznie robot nie poruszający się w określonej fazie programu zużywa energię na utrzymanie masy ramienia w pozornie "spoczynkowej” pozycji);

- wymagana duża dokładność i powtarzalność pozycjonowania w połączeniu ze znaczna dynamiką ruchów.

Pomocne w utrzymaniu dobrej kondycji robota, są oferowane przez importerów i integratorów programy serwisowe, odniesione do liczby godzin i/lub miesięcy przepracowanych pomiędzy przeglądami podstawowymi i pełnymi (np. ASTOR, ABB, Fanuc czy KUKA). Na rysunku 10 pokazano ideę stosowania takich programów w miejsce robota eksploatowanego bez jakiegokolwiek wsparcia.

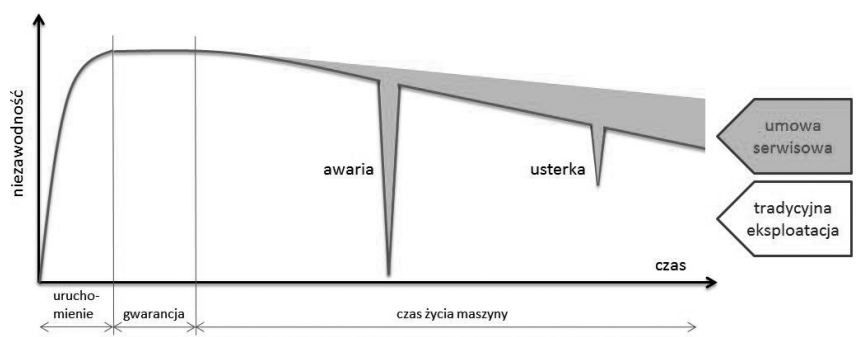

Rys. 10. Idea stosowania programu serwisowego (materiały informacyjne ABB)

Fig. 10. The idea of service programme application (ABB information matters)

Istotą tego typu usług jest nie tylko utrzymywanie robota w dobrej kondycji bez ryzyka unieruchamiających awarii, ale także szybkość reakcji serwisowej i usuwanie wszelkich usterek w początkowym stadium ich rozwoju.

Ciekawą propozycją jest proponowana przez firmę ABB usługa Remote Service, realizująca zdalne monitorowanie i diagnostykę stanu robota on-line 24 godziny/dobę, w tym wykrywanie usterek i stwierdzanie awarii. Według ABB, dla wielu zainstalowanych aplikacji szereg przestojów udaje się wyeliminować bez konieczności bezpośredniej ingerencji serwisu. Firma ASTOR, dystrybuująca roboty Kawasaki proponuje, obok planów serwisowych, możliwości wydzierżawienia lub odkupienia robota za z góry ustaloną kwotę $[1,7]$.
Poniżej, przytoczono wyniki wieloletnich obserwacji i badań spawalniczego robota IRp-6, eksploatowanego w warunkach laboratorium edukacyjnego (od roku 1991). O ile obciążenie godzinowe było dalekie od warunków przemysłowych, to na niekorzyść przemawiało częste włączanie oraz liczne drobne kolizje, nieuniknione w procesie nauczania. Badana jednostka, oparta na konstrukcji pierwszego na świecie uniwersalnego robota przemysłowego z napędem elektrycznym i sterowaniem mikroprocesorowym (ASEA IRB, 1975-1992), wyprodukowana została w ZAP Robotyka z Ostrowa Wielkopolskiego. Sześciokilogramowa nośność pięcioosiowego manipulatora antropomorficznego (osie obrotowe) pozwala na programowanie ruchów interpolowanych liniowo i kołowo z dobrą powtarzalnością pozycjonowania +/- 0,2 mm.

Jednym z pierwszych działań badawczych i dydaktycznych było wdrożenie autorskiej procedury kontroli pozycjonowania, opartej na ogólnych założeniach PN-EN 29283 (obecnie nieobowiązującej). Polegała ona na zaprogramowanym, wielokrotnym ruchu robota do tego samego punktu w przestrzeni, z cyklicznym najeżdżaniem zderzakiem na mechaniczny lub elektroniczny czujnik zegarowy (rys. 11). Wykonywano serie najazdów z kierunków X, Y i Z, odpowiadających bazowemu układowi współrzędnych robota. Na końcu ramienia instalowano dodatkowo obciążenie (3 kg - 50\% nośności nominalnej), a prędkość dojazdu do czujnika programowano w zakresie ok. $10 \div 50 \%$ prędkości maksymalnej. Po wyzerowaniu czujnika, podczas kolejnych najazdów rejestrowano odchyłkę, przeregulowanie i ewentualne oscylacje (gasnące lub nie), zgodnie z ogólnymi wytycznymi przedstawionymi na rysunku 4.

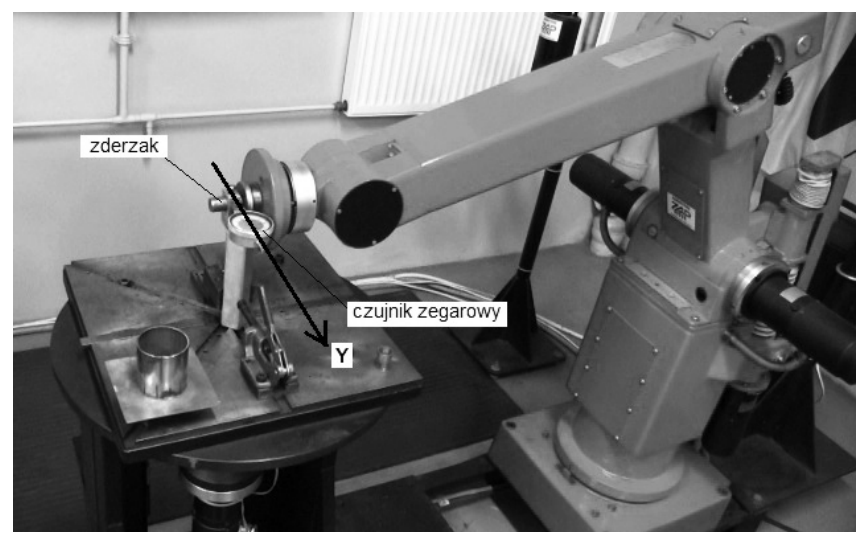

Rys. 11. Robot IRp-6 podczas kontroli pozycjonowania z najazdem w kierunku $Y$

Fig. 11. IRp-6 robot under positioning control with the movement along $Y$ axis

W pierwszych latach eksploatacji rejestrowane odchyłki oraz przeregulowania (głównie w kierunku Y, z szybko gasnącymi oscylacjami) nie przekraczały poziomu setnych części milimetra, a więc były znacznie nominalnej powtarzalności pozycjonowania robota. Pierwszą poważną modyfikacją (w roku 1999) było zastąpienie rezolwerów enkoderami w układach sprzężenia zwrotnego silników napędowych oraz całkowita wymiana jednostki centralnej układu sterowania (zastosowano m.in. 32-bitowy procesor Motoroli i system operacyjny czasu rzeczywistego OS-9). Widocznym skutkiem modernizacji było istotne zwiększenie dynamiki ramienia robota oraz możliwość dalszej rozbudowy komputera sterującego [6].

Pierwszym symptomem nadmiernego zużycia robota było widoczne nawet podczas pracy ręcznej przeregulowanie, objawiające się ruchem robota pomimo zaprzestania oddziaływania na ręczny sterownik. W pracy automatycznej również ujawniło się znaczne przeregulowanie oraz niegasnące oscylacje. W tablicy III zestawiono wybrane wyniki badań przeprowadzonych w roku 2008. 
Tablica III. Wybrane wyniki procedury kontroli pozycjonowania robota IRp-6 [8] Table III. Some results of test procedure of IRp-6 robot positioning control [8]

\begin{tabular}{|c|c|c|c|c|c|c|c|c|c|}
\hline \multirow{2}{*}{ L.p. } & Odchyłka & Przereg. & Oscylacja & Odchyłka & Przereg. & Oscylacja & Odchyłka & Przereg. & Oscylacja \\
\hline & \multicolumn{3}{|c|}{ Kierunek X } & \multicolumn{3}{|c|}{ Kierunek Y } & \multicolumn{3}{|c|}{ Kierunek Z } \\
\hline 1 & 0,01 & 0,35 & 0 & 0,03 & 0,67 & 0,04 & 0,02 & 0,64 & 0 \\
\hline 2 & 0,01 & 0,38 & 0 & 0,04 & 0,69 & 0,03 & 0,02 & 0,65 & 0,03 \\
\hline 3 & 0,01 & 0,38 & 0 & 0,04 & 0,71 & 0,04 & 0,02 & 0,67 & 0 \\
\hline 4 & 0,01 & 0,38 & 0 & 0,04 & 0,71 & 0,04 & 0,03 & 0,70 & 0 \\
\hline 5 & 0,01 & 0,39 & 0 & 0,04 & 0,72 & 0,03 & 0,02 & 0,70 & 0 \\
\hline 6 & 0,01 & 0,38 & 0 & 0,04 & 0,71 & 0,04 & 0,03 & 0,70 & 0 \\
\hline 7 & 0,01 & 0,38 & 0 & 0,02 & 0,71 & 0,01 & 0,03 & 0,70 & 0,01 \\
\hline 8 & 0,01 & 0,37 & 0 & 0,02 & 0,67 & 0,02 & 0,03 & 0,71 & 0,01 \\
\hline 9 & 0,01 & 0,37 & 0 & 0,02 & 0,67 & 0,04 & 0,03 & 0,71 & 0,01 \\
\hline 10 & 0,01 & 0,39 & 0 & 0,03 & 0,67 & 0,04 & 0,03 & 0,71 & 0 \\
\hline 11 & 0 & 0,37 & 0 & 0,02 & 0,7 & 0,02 & 0,02 & 0,58 & 0 \\
\hline 12 & 0 & 0,37 & 0 & 0,03 & 0,73 & 0,02 & 0,01 & 0,68 & 0 \\
\hline 13 & 0 & 0,37 & 0 & 0,02 & 0,75 & 0,02 & 0,02 & 0,73 & 0 \\
\hline 14 & 0 & 0,36 & 0 & 0,02 & 0,75 & 0,02 & 0,02 & 0,75 & 0 \\
\hline 15 & 0 & 0,37 & 0 & 0,01 & 0,76 & 0,05 & 0,02 & 0,75 & 0 \\
\hline 16 & 0 & 0,35 & 0 & 0,02 & 0,75 & 0,02 & 0,02 & 0,75 & 0 \\
\hline 17 & 0 & 0,36 & 0 & 0,01 & 0,76 & 0,04 & 0,02 & 0,75 & 0 \\
\hline 18 & 0 & 0,36 & 0 & 0,01 & 0,73 & 0,05 & 0,02 & 0,75 & 0 \\
\hline 19 & 0 & 0,37 & 0 & 0,01 & 0,74 & 0,04 & 0,02 & 0,76 & 0 \\
\hline 20 & 0 & 0,37 & 0 & 0,01 & 0,73 & 0,04 & 0,02 & 0,74 & 0 \\
\hline 21 & 0,01 & 0,42 & 0,01 & 0 & 0,55 & 0 & 0,04 & 0,69 & 0 \\
\hline 22 & 0,01 & 0,39 & 0,01 & 0 & 0,58 & 0 & 0,04 & 0,75 & 0 \\
\hline 23 & 0 & 0,38 & 0,01 & 0 & 0,61 & 0 & 0,04 & 0,75 & 0 \\
\hline 24 & 0 & 0,39 & 0,01 & 0 & 0,62 & 0 & 0,03 & 0,83 & 0 \\
\hline 25 & 0 & 0,39 & 0,01 & 0 & 0,61 & 0 & 0,04 & 0,85 & 0 \\
\hline 26 & 0 & 0,39 & 0,01 & 0 & 0,59 & 0 & 0,05 & 0,84 & 0 \\
\hline 27 & 0 & 0,38 & 0,01 & 0 & 0,59 & 0 & 0,04 & 0,79 & 0 \\
\hline 28 & 0 & 0,38 & 0,01 & 0 & 0,59 & 0 & 0,05 & 0,83 & 0 \\
\hline 29 & 0 & 0,38 & 0,01 & 0 & 0,59 & 0 & 0,05 & 0,85 & 0 \\
\hline 30 & 0 & 0,38 & 0,01 & 0 & 0,57 & 0 & 0,05 & 0,84 & 0 \\
\hline 31 & 0,01 & 0,35 & 0,01 & 0,01 & 0,70 & 0,02 & 0,02 & 0,70 & 0 \\
\hline 32 & 0,01 & 0,40 & 0,01 & 0 & 0,72 & 0,04 & 0,01 & 0,72 & 0,01 \\
\hline 33 & 0,01 & 0,39 & 0,01 & 0,02 & 0,73 & 0,02 & 0,01 & 0,73 & 0 \\
\hline 34 & 0,02 & 0,40 & 0,01 & 0,02 & 0,74 & 0,02 & 0,01 & 0,73 & 0,01 \\
\hline 35 & 0,01 & 0,39 & 0,01 & 0,01 & 0,75 & 0,02 & 0,01 & 0,74 & 0,01 \\
\hline 36 & 0,01 & 0,38 & 0,01 & 0,02 & 0,74 & 0,01 & 0,01 & 0,73 & 0,01 \\
\hline 37 & 0,02 & 0,40 & 0,01 & 0,01 & 0,74 & 0,02 & 0,01 & 0,73 & 0,01 \\
\hline 38 & 0,015 & 0,41 & 0,005 & 0,01 & 0,74 & 0,04 & 0,01 & 0,73 & 0,015 \\
\hline 39 & 0,02 & 0,39 & 0,01 & 0,015 & 0,75 & 0,04 & 0,02 & 0,73 & 0,01 \\
\hline 40 & 0,015 & 0,39 & 0,01 & 0,01 & 0,74 & 0,02 & 0,02 & 0,74 & 0,005 \\
\hline
\end{tabular}


Można zauważyć, że o ile odchyłka i oscylacje pozostały na poziomie nie wyższym niż $0,06 \mathrm{~mm}$, to przeregulowanie, w każdym z analizowanych kierunków, przekroczyło poziom 0,2 mm - zadeklarowanej przez producenta powtarzalności pozycjonowania. Znaczne różnice pomiędzy grupami wyników tłumaczy fakt, że zestawiono je z czterech sesji (po 10 pomiarów w każdym kierunku), przy różnym stopniu rozgrzania mechanizmów i sterowników. Seria trzecia, z uwagi na znaczne różnice zarejestrowanych danych, została odrzucona z dalszej analizy. Należy dodać, że obok badań autora, w każdym roku powstawało kilkaset pomiarów w ramach ćwiczeń dydaktycznych.

Wobec braku zewnętrznych symptomów zużycia mechanicznego manipulatora uznano, że powodem narastających problemów mogło być zużycie przestarzałych, tranzystorowych sterowników osi (serwowzmacniaczy) TAR 1A3, w znaczniej mierze opartych na podzespołach dyskretnych, w tym dużej ilości zawodnych kondensatorów elektroli- tycznych i miniaturowych potencjometrów. W ramach modernizacji zastosowano nowoczesne układy mikroprocesorowe Mini Maestro 60x14/28 firmy Control Techniques. Niestety, nie uzyskano w pełni satysfakcjonującego rezultatu. O ile nastąpiła ogólna poprawa w niemal każdym aspekcie pozycjonowania robota (oscylacje wyeliminowano całkowicie w kierunkach osi X i Z, a w Y znacznie ograniczono), to nadal poziomy przeregulowania znacznie przekraczały $0,2 \mathrm{~mm}$ (tabl. IV).

Do chwili obecnej następuje dalsze pogarszanie się kondycji robota, przede wszystkim przeregulowanie. Powodem nie były, jak pierwotnie przypuszczano, jedynie przestarzałe układy elektroniczne (serwowzmacniacze), a przede wszystkim nadmiernie zużyte układy mechaniczne manipulatora, w tym luzy, drobne zatarcia itp. cięgien, popychaczy i przekładni. Odrębnym, w tym przypadku niestwierdzonym źródłem błędów pozycjonowania mogą być przekłamania w układach sensorycznych ruchu (serwonapędów).

Tablica IV. Wybrane wyniki procedury kontroli pozycjonowania robota IRp-6 [8]

Table IV. Comparison of IRp-6 robot positioning before and after servo-amplifiers exchanging [8]

\begin{tabular}{|c|c|c|c|c|}
\hline \multicolumn{2}{|c|}{ Badana wielkość } & Przed modernizacją & Po modernizacji & Korzyść \% \\
\hline Odchyłka & \multirow{3}{*}{$x$} & 0,0076 & 0,0033 & 56,5 \\
\hline Przeregulowanie & & 0,3773 & 0,3726 & 1,2 \\
\hline Oscylacja & & 0,0030 & 0 & 100 \\
\hline Odchyłka & \multirow{3}{*}{ Y } & 0,0191 & 0,0100 & 47,8 \\
\hline Przeregulowanie & & 0,7226 & 0,7240 & $-0,01$ \\
\hline Oscylacja & & 0,0296 & 0,0093 & 68,5 \\
\hline Odchyłka & \multirow{3}{*}{ Z } & 0,0193 & 0,0220 & $-13,7$ \\
\hline Przeregulowanie & & 0,7136 & 0,5886 & 17,5 \\
\hline Oscylacja & & 0,0038 & 0 & 100 \\
\hline
\end{tabular}

\section{Podsumowanie}

Nieprawidłowa, odbiegająca od linii prostej trajektoria ruchu robota podczas spawania łukowego MIG/MAG może wiązać się z prozaicznym i najczęściej łatwym do naprawienia stosowaniem instrukcji ruchu bez interpolacji.

Groźnym i pociągającym istotne obciążenia materialne źródłem dysfunkcji może być nadmiernie zużyty, w tym także nieprawidłowo eksploatowany manipulator. Doświadczenia własne wskazują, że głównym powodem nieprawidłowej pracy robota są przede wszystkim nadmiernie zużyte układy mechaniczne manipulatora, w tym luzy, drobne zatarcia, wyciągnięcie pasów przekładniowych itp. Sposobem na długotrwałe utrzymanie robota $w$ dobrej kondycji może być regularna kontrola jego stanu w połączeniu z niezbędnymi czynnościami obsługowymi. Dobrą pomocą mogą być liczne programy serwisowe oferowane przez importerów, integratorów i producentów robotów.

\section{Literatura}

[1] Biega D.: Diagnostyka i monitoring jednostek mechanicznych i kontrolerów, Biuletyn Automatyki (ASTOR) 1/2010, str. 32-33.

[2] Cegielski P.: Analiza uwarunkowań zapewnienia punktu roboczego narzędzia w zrobotyzowanych aplikacjach MIG/MAG, Przegląd Spawalnictwa $8 / 2014$, str. 34-40.

[3] Cegielski P.: Wybrane aspekty orientacji przestrzennej głowicy roboczej podczas zmechanizowanego i zautomatyzowanego spawania łukowego, Przegląd Spawalnictwa 2/2016, str. 35-40

[4] Cegielski P., Kolasa A., Sarnowski T.: Dostosowanie robotów do spawania elementów o obniżonej dokładności, Przegląd Spawalnictwa 6/2011, str. 25-28.

[5] Honczarenko J.: Roboty przemysłowe. Budowa i zastosowanie. WNT Warszawa 2011.
[6] Kolasa A., Cegielski P.: Fully Automatic GMAW installation, 9th International Conference on Computer Technology in Welding, 28-30.09.1999, Detroit, Mich. USA

[7] Michałek T.: Program RaaS (Robot as a Service), Biuletyn Automatyki (ASTOR) 4/2013, str. 10-11

[8] Mierzwa P.: Modernizacja sterowników osi robota IRp-6. Uruchomienie i badanie laboratoryjne po modernizacji, Praca dyplomowa inżynierska pod kierunkiem dr inż. Pawła Cegielskiego, Politechnika Warszawska 2015.

[9] Olszewski M. i inni: Manipulatory i roboty przemysłowe, WNT, Warszawa 1992.

[10] Rygałło A.: Robotyka dla mechatroników, Projekt POKL.04.01.01-00059/08, Częstochowa 2008. 